\title{
Analgesic Action by Neuroleptics in Diabetic State
}

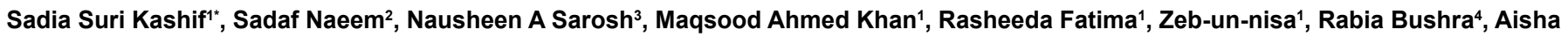 Jabeen ${ }^{1}$, Mudassar Hassain ${ }^{5}$ and Muhammad Akram ${ }^{5}$}

'Ziauddin University, Karachi, Pakistan

2Jinnah Sindh Medical University, Karachi, Pakistan

${ }^{3}$ Federal Urdu University of Arts, Science \& Technology, Karachi, Pakistan

${ }^{4}$ Dow college of Pharmacy, Dow University of Health Sciences, Pakistan

${ }^{5}$ Department of Pharmaceutics, University of Karachi, Pakistan

\begin{abstract}
Purpose: To assess the analgesic role of neuroleptics in hyperglycemic state.

Methods: Amytryptiline and carbamazepine were selected for study. This study was carried out at Pharmacology lab, Institute of Research Pharmaceutical sciences, University of Karachi, and comprised of male and female mice half of which were made diabetic by giving Alloxan. The objective of this study is to monitor the effects of neuroactive agents on analgesic activity in hyperglycemic mice.
\end{abstract}

Results: It was observed that Amytryptiline exhibited highly significant analgesic effect in normal as compared to diabetic subjects. It was also observed that both amytryptiline and carbamazepine produce more rapid onset of action and longer duration of action in normal animals when compared with diabetic animals.

Conclusion: The present work on normal and diabetic animals show that both Carbamazepine and Amytryptiline in normal animals produce rapid onset and longer duration of action when compared with diabetic animals.

Keywords: Diabetes; Hyperalgesia; Diabetic neuropathy; Amytryptiline; Carbamazepine

\section{Introduction}

Pain is a complex process in the central nervous system (CNS). Several factors can alter the pain threshold and insulin is one of them produced by the beta cells of pancreas and capable of crossing blood-brain barrier. Diabetes mellitus is a serious complication in which insulin release from pancreatic cells become decreased [1]. In type-1 diabetes, the nutritional and environmental factors produce oxidative stress and modify immune response by arbitrating gene expression of cytokines causing immune mediated loss of beta cells. In type 2 diabetes mellitus, imbalance in glycemic control induces lipotoxicity and glucotoxicity, disclosing the cellular surroundings to free fatty acid, which causes insulin resistance due to apoptosis in beta cells. The failure of functional beta cell mass in pancreas is the main characteristic of tissue injury in type 1 or type 2 diabetes. Oxidative stress plays a significant role in the pathogenesis of beta cell damage in diabetes and its complications. The pathophysiology of diabetes also involves imbalance of reactive nitrogen and reactive oxygen species [2].

Peripheral diabetic neuropathy has been thought to be irreversible and progressive complication of diabetes. It is long term and shows difficult to relieve. Neuropathy can be caused by a disease or a lesion of somatosensory system involving peripheral ( $\mathrm{A} \delta, \mathrm{A} \beta$ and $\mathrm{C}$ ) fibers of central neurons. It effects $7-10 \%$ of general population. Many causes of neuropathic pain have been reported in past years that include alteration in ion channels, imbalances between inhibitory and excitatory somatosensory signaling and irregularity in modulation of the pain messages in the central nervous system. Despite challenges, advancement in understanding pathophysiology of neuropathic pain is motivating the growth of novel interventions and diagnostic procedures, which evince the need for a multidimensional approach for managing neuropathic pain [3]. Furthermore, insulin receptors are generally distributed in the CNS [4]. It has been indicated that insulin has an ameliorative effect in rodents in the pain test [5]. The pain control centres in the brain stem have expressed insulin receptors and up to now no study has been done on the central anti-nociceptive effect of insulin. According to the presence of insulin receptors in the CNS, CNS can be considered as a target of the anti-nociceptive effect of insulin.

Many anticonvulsant drugs decrease abnormal discharge at nerve injury sites and associated areas by blocking sodium channels [6]. Tricyclic antidepressants and anticonvulsants have long been the mainstay of treatment of this type of pain. Tricyclic antidepressants may relieve neuropathic pain by their unique ability to inhibit presynaptic reuptake of the biogenic amines serotonin and noradrenaline, but other mechanisms such as N-methyl-Daspartate receptor and ion channel blockade probably also play a role in their pain-relieving effect. The effect of tricyclic antidepressants in neuropathic pain in man has been demonstrated in numerous randomized, controlled trials, and a few trials have shown that serotonin, noradrenaline and selective serotonin reuptake inhibitor antidepressants also relieve neuropathic pain although with lower efficacy [7].

Previous clinical data shows that pain in diabetic complications like neuropathy, trigeminal neuralgia and diabetic foot ulcers can be better treated with anticonvulsants, antidepressants, co-analgesics and topical agents. The objective of this study is to monitor the analgesic

*Corresponding author: Sadia Suri Kashif, Ziauddin University, Karachi, Pakistan, Tel: 03412489472; E-mail: misssadia67@gmail.com

Received March 09, 2018; Accepted March 26, 2018; Published April 05, 2018

Citation: Kashif SS, Naeem S, Sarosh NA, Khan MA, Fatima R, et al. (2018) Analgesic Action by Neuroleptics in Diabetic State. J Bioequiv Availab 10: 29-32. doi: 10.4172/0975-0851.1000373

Copyright: @ 2018 Kashif SS, et al. This is an open-access article distributed under the terms of the Creative Commons Attribution License, which permits unrestricted use, distribution, and reproduction in any medium, provided the original author and source are credited. 
Citation: Kashif SS, Naeem S, Sarosh NA, Khan MA, Fatima R, et al. (2018) Analgesic Action by Neuroleptics in Diabetic State. J Bioequiv Availab 10: 29-32. doi: 10.4172/0975-0851.1000373

effects of neuroactive agents in hyperglycemic state in animal model. Amytryptiline, an antidepressant and carbamazepine, an antiepileptic were selected for the study.

\section{Experimental}

\section{Animals}

Balb-C mice weighing 25-30 gm were used procured from the Aga Khan University Hospital. The animals were housed in 5 groups in standard cages of glass with access to water and food freely and were kept at room temperature.

\section{Drugs and chemicals}

Alloxan purchased from Sigma laboratories were used to induce hyperglycemia in mice. Drugs include Carbamazepine and amytryptiline was used in this study at an oral dose of $26 \mathrm{mg} / \mathrm{Kg}$ and $9.75 \mathrm{mg} / \mathrm{Kg}$ respectively calculated from human dose as depicted by Paget and Barnes, [8] 1964.

\section{Induction of experimental diabetes}

To induce hyperglycemia, modified methods of Niedzielski \& Esmerino [9] were used. Alloxan tetrahydrate in a dose of $160 \mathrm{mg} / \mathrm{Kg}$ just once was given i.p and tests were performed after 48 hours. Animals having a blood sugar level of more than $165 \mathrm{mg} / \mathrm{dl}$ were considered hyperglycemic. Drugs were given to both normal and diabetic groups orally by using intubation tube.

\section{Tail flick method}

Each mouse was held in a proper restrainer with the whole tail extending out. An area of tail, $2-5 \mathrm{~cm}$ in length was marked and dipped in a water bath thermo statistically maintained at $51-52^{\circ} \mathrm{C}$. The characteristic flick time of tail from hot water (in seconds) was noted as the flick time [10]. The test was repeated thrice for each mouse and the average was recorded.

\section{Experimental Design}

For each drug, there are two major groups and each major group has two sub-groups.

\section{Normal}

Control $(n=5) \&$ Test $(n=5)$.

2. Diabetic

Control (n=5) \& Test $(n=5)$.
The control animals of both groups received saline $(0.9 \% \mathrm{NaCl})$, while the test group received the test drug.

\section{Statistical Analysis}

TWO-WAY ANOVA was used for statistical analysis. Intergroup comparisons were done by Newman-Keuls statistics.

\section{Results}

Both drugs showed significant results and diabetic animals also clearly demonstrated an increased sensitivity to pain. The results were highly significant after even 10 minutes and also showed significant response even after 120 minutes as shown in both tables and graphs.

It was observed that Amytryptiline exhibited highly significant analgesic effect in normal as compared to diabetic subjects as depicted by Table 1 and Graph 1. It was also observed that both amytriptylene and carbamazepine produce more rapid onset of action and longer duration of action in normal animals when compared with diabetic animals.

\section{Discussion}

Carbamazepine and Amytryptiline are used for treating neuropathic pain but their analgesic effect on sensory neurons is not thoroughly understood. Hyperglycemia alters pain sensitivity by inducing mechanical, chemical and thermal hyperalgesia.

In present study, Carbamazepine, an anti-epileptic agent had produced significant analgesic effect in normal animals as compared to diabetic subjects $(\mathrm{P}<0.05)$, mentioned in Table 2 and Graph 2, which is in accordance with previous research that demonstrates that neuroactive drugs inhibits the presynaptic reuptake of the monoamines, serotonin, noradrenaline and have no effect on dopamine reuptake but may have some indirect dopaminergic action by the adrenergic effect and desensitization of dopamine D2 receptors [11-14]. These biogenic amines inhibition is associated with a marked inhibition of glucose-stimulated insulin secretion from pancreatic islets and also inhibit the increase in cellular reducing power stimulated by glucose [15]. This insulin inhibition may reduce the pain perception as previous studies state that voltage gated ion channels modulation in central nervous system leads to antinociceptive effects of these drugs [16]. CBZ decreases the repetitive firing of action potentials induced by a sustained depolarization by declining the rate of recovery of voltage activated sodium channels. CBZ suppress the thermal nociception [6].

\begin{tabular}{|c|c|c|c|c|c|c|c|}
\hline & \multicolumn{2}{|c|}{ Normal } & \multicolumn{2}{|c|}{ Diabetic } & \multicolumn{2}{|c|}{ Two-way ANOVA } & \multirow{2}{*}{$\begin{array}{c}\text { df }(2,16) \\
\text { Amitriptylene \& } \\
\text { Diabetes Interaction }\end{array}$} \\
\hline & Saline & Test & Saline & Test & Amitriptylene & Diabetes & \\
\hline $10 \mathrm{~min}$ & $1.0 \pm 0.11$ & $7.42 \pm 0.71^{* *}$ & $1.54 \pm 0.26^{+}$ & $3.48 \pm 0.16^{*++}$ & $\begin{array}{c}F=558.25 \\
P<0.01\end{array}$ & $\begin{array}{l}F=95.43 \\
P<0.01\end{array}$ & $\begin{array}{c}F=158.98 \\
P<0.01\end{array}$ \\
\hline $30 \mathrm{~min}$ & $1.28 \pm 0.13$ & $7.4 \pm 1.03^{* *}$ & $1.62 \pm 0.27^{++}$ & $6.52 \pm 0.57^{+++}$ & $\begin{array}{c}F=407.24 \\
P<0.01\end{array}$ & $\begin{array}{c}F=0.977 \\
P=N S\end{array}$ & $\begin{array}{l}F=4.99 \\
P<0.01\end{array}$ \\
\hline $60 \mathrm{~min}$ & $1.56 \pm 0.37$ & $7.28 \pm 0.40^{* *}$ & $2.78 \pm 0.43^{++}$ & $5.6 \pm 0.42^{*+++}$ & $\begin{array}{c}F=551.21 \\
P<0.01\end{array}$ & $\begin{array}{l}F=1.07 \\
P=N S\end{array}$ & $\begin{array}{l}F=58.99 \\
P<0.01\end{array}$ \\
\hline $90 \mathrm{~min}$ & $1.26 \pm 0.19$ & $4.76 \pm 0.24^{* *}$ & $2.14 \pm 0.27^{++}$ & $4.56 \pm 0.27^{*++}$ & $\begin{array}{c}F=724.10 \\
P<0.01\end{array}$ & $\begin{array}{l}F=9.55 \\
P<0.01\end{array}$ & $\begin{array}{c}F=24.09 \\
P<0.01\end{array}$ \\
\hline $120 \mathrm{~min}$ & $1.26 \pm 0.27$ & $4.58 \pm 0.34^{* *}$ & $3.08 \pm 0.33^{++}$ & $2.02 \pm 0.13^{\prime \prime++}$ & $\begin{array}{l}F=80.05 \\
P<0.01\end{array}$ & $\begin{array}{l}F=8.58 \\
P<0.01\end{array}$ & $\begin{array}{c}F=300.69 \\
P<0.01\end{array}$ \\
\hline
\end{tabular}

Values are mean + S.D $(n=5)$. Significant differences by Newman-Keuls test ${ }^{*} p<0.05,{ }^{* *} p<0.01$, as compared to saline injected rats, ${ }^{*} p<0.05$, " $p<0.01$ as compared to normal mice following Two Way ANOVA df $(2,16)$. 
Citation: Kashif SS, Naeem S, Sarosh NA, Khan MA, Fatima R, et al. (2018) Analgesic Action by Neuroleptics in Diabetic State. J Bioequiv Availab 10: 29-32. doi: 10.4172/0975-0851.1000373

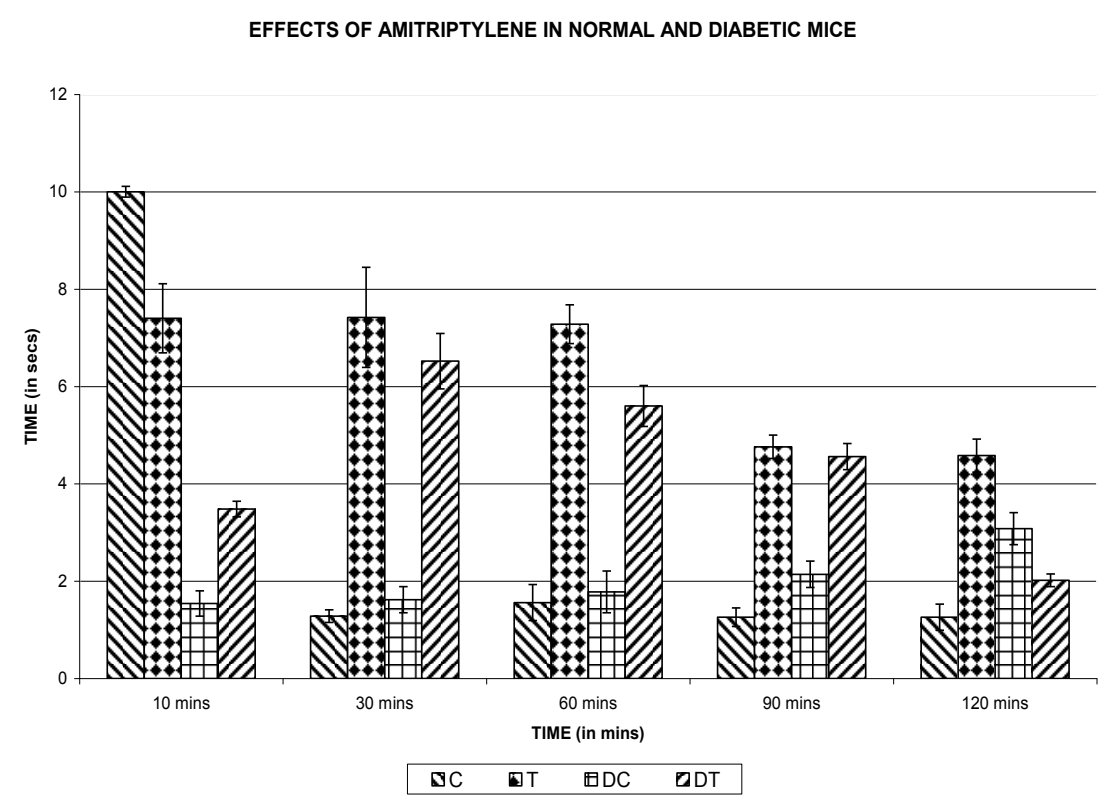

Graph 1: Values are mean + S.D. $(n=5)$. Significant differences by Newman-Keuls test following Two Way ANOVA df $(2,16)$.

\begin{tabular}{|c|c|c|c|c|c|c|c|}
\hline & Saline & Test & Saline & Test & Carbamazepine & Diabetes & \\
\hline $10 \mathrm{~min}$ & $1.2 \pm 0.22$ & $6.84 \pm 0.38^{* *}$ & $2.08 \pm 0.23^{++}$ & $5.22 \pm 0.23^{*++}$ & $\begin{array}{c}F=1235.43 \\
P<0.01\end{array}$ & $\begin{array}{l}F=8.77 \\
P<0.01\end{array}$ & $\begin{array}{c}F=100.16 \\
P<0.01\end{array}$ \\
\hline $30 \mathrm{~min}$ & $1.12 \pm 0.19$ & $8.28 \pm 0.38^{* *}$ & $1.96 \pm 0.16^{++}$ & $4.82 \pm 0.19^{*++}$ & $\begin{array}{c}F=1976.34 \\
P<0.01\end{array}$ & $\begin{array}{l}F=135.12 \\
P<0.01\end{array}$ & $\begin{array}{c}F=363.96 \\
P<0.01\end{array}$ \\
\hline $60 \mathrm{~min}$ & $1.04 \pm 0.23$ & $7.74 \pm 0.33^{* *}$ & $1.80 \pm 0.47^{++}$ & $4.2 \pm 0.4^{+*++}$ & $\begin{array}{c}F=740.61 \\
P<0.01\end{array}$ & $\begin{array}{l}F=66.55 \\
P<0.01\end{array}$ & $\begin{array}{c}F=160.88 \\
P<0.01\end{array}$ \\
\hline $90 \min$ & $1.48 \pm 0.23$ & $4.04 \pm 0.27^{*}$ & $2.42 \pm 0.71^{++}$ & $3.64 \pm 0.30^{++}$ & $\begin{array}{c}F=96.54 \\
P<0.01\end{array}$ & $\begin{array}{l}F=1.97 \\
P=N S\end{array}$ & $\begin{array}{l}F=12.13 \\
P<0.01\end{array}$ \\
\hline $120 \mathrm{~min}$ & $1.66 \pm 0.15$ & $7.26 \pm 0.35^{* *}$ & $2.56 \pm 0.11^{++}$ & $4.18 \pm 0.44^{*++}$ & $\begin{array}{c}F=732.11 \\
P<0.01\end{array}$ & $\begin{array}{l}F=66.74 \\
P<0.01\end{array}$ & $\begin{array}{c}F=222.47 \\
P<0.01\end{array}$ \\
\hline
\end{tabular}

Values are mean $\pm S . D(n=5)$. Significant differences by Newman-Keuls test $" p<0.05, " p<0.01$, as compared to saline injected rats, "p<0.05, "p $<0.01$ as compared to normal mice following Two Way ANOVA df $(2,16)$.

Table 2: Effect of carbamazepine in normal \& diabetic mice.

EFFECTS OF CARBAMEZAPIME IN NORMAL AND DIABETIC MICE

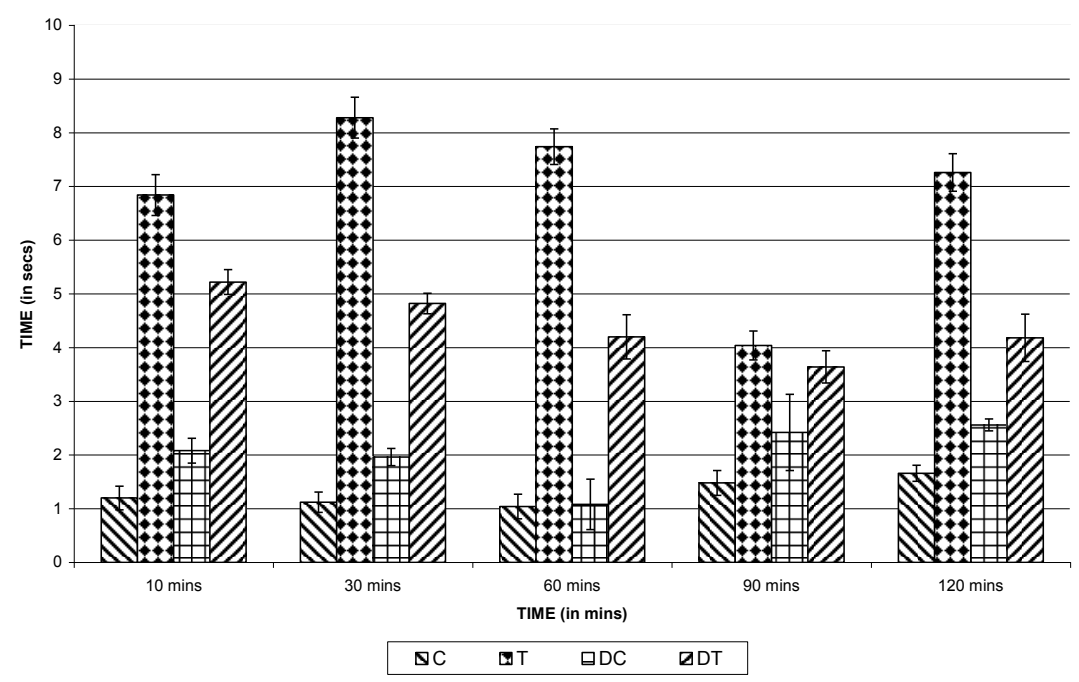

Graph 2: Values are mean + S.D. $(n=5)$. Significant differences by Newman-Keuls test following Two Way ANOVA df $(2,16)$. 
Citation: Kashif SS, Naeem S, Sarosh NA, Khan MA, Fatima R, et al. (2018) Analgesic Action by Neuroleptics in Diabetic State. J Bioequiv Availab 10: 29-32. doi: 10.4172/0975-0851.1000373

Diabetes mellitus is a chronic metabolic disorder that is associated with neurological complications including alterations in nociception behaviour [17]. Previous studies have reported that hyperglycemia increased the pain sensitivity [18]. In present study, diabetic hyperalgesia and allodynia in diabetic rats was observed two weeks after induction of diabetes with naloxone, carbamazepine and amytryptiline reversed this action with profound reduction in pain which represents that Amytryptiline, an antidepressant, exhibited highly significant analgesic effect.

Previous studies have shown that antidepressants produce analgesic effects without effecting mood in patients with chronic pain with or without depression. This is probably due to improvement of descending monoaminergic inhibitory pathways by blocking serotonin and noradrenalin reuptake centrally. Alpha-adrenergic, muscarinic cholinergic, histaminergic and blockade of calcium and sodium channels are also reported [19].

Earlier reports showed that TCAs have been used for centuries in managing chronic pain syndromes in patients without depression. However, the mechanism for analgesia is not clear, and it involves an indirect and direct mechanism on receptors of opioid and pathways that involve the release of endogenous peptide possibly. Serotonergic or noradrenergic pathways mediate the activation of an analgesic mixed effect or merging of these mechanisms also has been proposed [20]. These drugs have agonistic effect on MT1/MT2 receptor while inhibiting 5HT2C receptor causing indirect release of norepinephrine. Serotonin, norepinephrine and melatonin are known to be involved in the pathophysiology of neuropathic pain.

\section{Conclusion}

The present work on normal and diabetic animals show that both Carbamazepine and Amytryptiline in normal animals produce rapid onset of action and longer duration of action when compared with diabetic animals. Diabetes can induce certain changes in the pharmacokinetic and pharmacodynamic aspects of analgesic agents. Comparison between normal and diabetic vasculature might be helpful in better understanding of the vascular complications of diabetes and prove fruitful in developing pharmacological therapy for diabetic patients.

\section{Declarations}

\section{Acknowledgement}

This work was supported by the Department of Pharmacology, Faculty of Pharmaceutical Sciences, University of Karachi, Pakistan.

\section{Conflict of Interest}

No conflict of interest associated with this work

\section{Contribution of Authors}

The authors declare that the authors named in this article did this work and all liabilities pertaining to claims relating to the content of this article will be borne by them.

\section{References}

1. Dehkordi SB, Sajedianfard J, Owji AA (2017) The effect of intracerebroventricular injection of insulin on nociception of formalin test in nondiabetic and short-term diabetic rat models. Iran J Vet Res 18: 108-112.

2. Amin A, Tahir M, Lone KP (2017) Effect of Citrullus colocynthis aqueous seed extract on beta cell regeneration and intra-islet vasculature in alloxan induced diabetic male albino rats. J Pak Med Assoc 67: 5.

3. Colloca L, Ludman, T, Bouhassira D, Baron R, Dickenson AH, et al. (2017) Neuropathic pain. Nature Reviews 3: 17002.

4. Schulingkamp RJ, Pagano TC, Hung D, Raffa RB (2000) Insulin receptors and insulin action in the brain: review and clinical implications. Neurosci Biobehav Rev 24: 855-872.

5. Takeshita N, Yamaguchi I (1997) Insulin attenuates formalin-induced nociceptive response in mice through a mechanism that is deranged by diabetes mellitus. J Pharmacol Exp Ther 281: 315-321.

6. Mahmood S, Abdullah S, Ahmad N, Mohamed A, Razak T (2016) Analgesic synergism of gabapentin and carbamazepine in rat model of diabetic neuropathic pain. Trop J Pharm Res 15: 1191-1195.

7. Sindrup SH, Otto M, Finnerup NB, Jensen TS (2005) Antidepressants in the treatment of neuropathic pain. Basic Clin Pharmacol Toxicol 96: 399-409.

8. Laurence DR, Bacharach AL (1964) Evaluation of drug activities: pharmacometrics (Vol. 900), New Academic press, New York, USA.

9. Niedzielski K (2000) Effect of Coccinia indica on Blood Glucose Levels in Alloxan-induced Diabetic Mice.

10. Saify ZS, Mushtaq N, Noor F (2000) Analgesic and Ant microbial activity of the leaves extract of Calendula officinalis. Hamdard Medicus Volume 43: 35.

11. Max MB, Culnane M, Schafer SC, Gracely RH, Walther DJ, et al. (1987) Amitriptyline relieves diabetic neuropathy pain in patients with normal or depressed mood. Neurology 37: 589-596.

12. Max MB, Schafer SC, Culnane M, Smoller B, Dubner R, et al. (1988) Amitriptyline, but not lorazepam, relieves postherpetic neuralgia. Neurology 38 : 1427-1432.

13. Leijon G, Boivie J (1989) Central post-stroke pain--a controlled trial of amitriptyline and carbamazepine. Pain 36: 27-36.

14. Kumar K, Max MB, Lawlor BA, Murphy DL (1990) Central post-stroke pain--a controlled trial of amitriptyline and carbamazepine. Pain 37: 223-227.

15. Jain R, Jain D, Liu Q, Bartosinska B, Wang J, et al. (2013) Pharmacological inhibition of Eph receptors enhances glucose-stimulated insulin secretion from mouse and human pancreatic islets. Diabetologia. (2013) Jun; 56: 1350-1355.

16. Wolff M, Czorlich P, Nagaraj C, Ehehalt R, Li Y, et al. (2016) Amytriptylene and carbamazepine utilize voltage-gated ion channel suppression to impair excitability of sensory dorsal horn neurons in thin tissue slice: An in vitro study. Neuroscience Research 109: 16-27.

17. Rutledge LP, Gong MN, Kuperberg JM, Samaan SS, Soliman FA, et al. (2002) Dopaminergic system modulation of nociceptive response in long-term diabetic rats. Pharmacol Biochem Behav 74: 1-9.

18. Ibironke GF, Saba OJ, Olopade FO (2004) Glycemic control and pain threshold in alloxan diabetic rats. Afr J Biomed Res 7.

19. Kumar A, Pottabathini R, Bhatnagar A, Garg S, Gupta V (2017) Pharmacological Management of Neuropathic Pain: Current Trends and Possible Approaches. Arch Neurosci 4: e28998.

20. Zarrindast MR, Vousooghi N, Saxebghara M (2003) Imipramine induced antinociception in the formalin test. Pharmacology 68: 154-161. 